\title{
Enteroviral Infections in the First Three Months of Life
}

\author{
Marcello Sandoni ${ }^{1}$, Lidia Ciardo ${ }^{1}$, Caterina Tamburini ${ }^{1}$, Alessandra Boncompagni ${ }^{2}$, Cecilia Rossi ${ }^{2}$, \\ Isotta Guidotti ${ }^{2}$, Elisabetta Garetti ${ }^{2}$, Licia Lugli ${ }^{2, *}$, Lorenzo Iughetti ${ }^{1,3}$ and Alberto Berardi ${ }^{2}$ (D)
}

1 Pediatric Post-Graduate School, University of Modena and Reggio Emilia, 41125 Modena, Italy; marcello.sandoni@gmail.com (M.S.); lidiaciardo@libero.it (L.C.); cate.tamburini@gmail.com (C.T.); lorenzo.lughetti@unimore.it (L.I.)

2 Neonatal Intensive Care Unit, Women's and Children's Health Department, Azienda Ospedaliera, University of Modena and Reggio Emilia, 41125 Modena, Italy; boncompagni.alessandra@aou.mo.it (A.B.); rossi.cecilia@aou.mo.it (C.R.); guidotti.isotta@aou.mo.it (I.G.); garetti.elisabetta@aou.mo.it (E.G.); alberto.berardi@unimore.it (A.B.)

3 Pediatric Unit, Women's and Children's Health Department, Azienda Ospedaliera, University of Modena and Reggio Emilia, 41125 Modena, Italy

* Correspondence: lugli.licia@aou.mo.it; Tel.: +39-0594-2225-22

check for

updates

Citation: Sandoni, M.; Ciardo, L.; Tamburini, C.; Boncompagni, A.; Rossi, C.; Guidotti, I.; Garetti, E.; Lugli, L.; Iughetti, L.; Berardi, A. Enteroviral Infections in the First Three Months of Life. Pathogens 2022, 11, 60. https://doi.org/10.3390/ pathogens 11010060

Academic Editors: Amirbabak Sioofy-Khojine and Carl Kirkwood

Received: 12 November 2021 Accepted: 30 December 2021 Published: 3 January 2022

Publisher's Note: MDPI stays neutral with regard to jurisdictional claims in published maps and institutional affiliations.

Copyright: (C) 2022 by the authors. Licensee MDPI, Basel, Switzerland. This article is an open access article distributed under the terms and conditions of the Creative Commons Attribution (CC BY) license (https:// creativecommons.org/licenses/by/ $4.0 /)$.

\begin{abstract}
Enteroviruses (EVs) are an important source of infection in the paediatric age, with most cases concerning the neonatal age and early infancy. Molecular epidemiology is crucial to understand the circulation of main serotypes in a specific area and period due to their extreme epidemiological variability. The diagnosis of EVs infection currently relies on the detection of EVs RNA in biological samples (usually cerebrospinal fluid and plasma, but also throat swabs and feces) through a polymerase chain reaction assay. Although EVs infections usually have a benign course, they sometimes become life threatening, especially when symptoms develop in the first few days of life. Mortality is primarily associated with myocarditis, acute hepatitis, and multi-organ failure. Neurodevelopmental sequelae have been reported following severe infections with central nervous system involvement. Unfortunately, at present, the treatment of EVs infections is mainly supportive. The use of specific antiviral agents in severe neonatal infections has been reported in single cases or studies including few neonates. Therefore, further studies are needed to confirm the efficacy of these drugs in clinical practice.
\end{abstract}

Keywords: enterovirus; neonate; infant; infection; treatment

\section{Introduction}

Enteroviruses (EVs) are small single-stranded, positive sense RNA viruses belonging to the family Picornaviridae. This family also includes the genera Parechovirus and Hepatovirus. The genus Enterovirus also encompasses the species Rhinovirus A, B, and C. Thanks to molecular typing methods, more than one hundred EVs serotypes are known to infect humans and have been recently reclassified into four species (from A to D), as reported in Table 1 [1,2].

In micrographs, the viruses are 27- to $30-\mathrm{nm}$ particles and show icosahedral nonenveloped capsids and dense cores containing the genomic RNA, which is approximately $7.5 \mathrm{~kb}$ in length. Enteroviral infection of the cell begins with the interaction of the virion with one or more cell surface protein and receptors, which are usually represented by integrins or immunoglobuline-like proteins. These receptors have been identified for some serotypes. For example, coxsackievirus B1-6 are known to interact with the coxsackie and adenovirus receptor (CAR) and some coxsackievirus A serotypes use the intercellular adhesion molecule 1 (ICAM-1). Following attachment of the virus, recruitment of additional cellular receptors occurs, and the virion is enveloped by cell membrane. A steric shift in the capsid conformation occurs, resulting in uncoating and release of RNA freely into the cellular cytoplasm, where it rapidly binds to ribosomes and begins protein synthesis. A 
single polypeptide is produced, which is almost instantaneously auto-cleaved by viral proteases. This polyprotein contains three domains, P1 to P3. The structural protein VP1 to VP4 originates from the cleavage of the P1 domain. Portions of VP1, VP2 and VP3 are exposed on the surface of the capsid, whereas VP4 is completely internal. The replication of enteroviruses occurs in the cytoplasm and is completed rapidly in 5-10 h [3].

Table 1. Classification of Enteroviruses.

\begin{tabular}{cc}
\hline Species & Serotypes \\
\hline Enterovirus A (HEV-A) & $\begin{array}{c}\text { Coxsackievirus A2-8, A10, A12, A14, A16 } \\
\text { Enterovirus A71, A76, A89-91, A114, A119-121 }\end{array}$ \\
\hline Enterovirus B (HEV-B) & $\begin{array}{c}\text { Coxsackievirus A9 } \\
\text { Coxsackievirus B1-6 }\end{array}$ \\
& Enterovirus B69, B73-75, B77-88, B93, B97, B98, B100, B101, B106, B107 \\
\hline Enterovirus C (HEV-C) & Poliovirus 1-3 \\
& Coxsackievirus A1, A11, A13, A17, A19-22, A24 \\
\hline Enterovirus D (HEV-D) & Enterovirus C95, C96, C99, C102, C104, C105, C109, C113, C116-118 \\
\hline Adapted from reference [1,2]. & Enterovirus D68, D70, D94, D111 \\
\hline
\end{tabular}

Phylogenetic analysis has revealed that circulating EVs have high mutation rates and frequently undergo recombination, leading to increased genetic diversity, which explains the widespread epidemic and sporadic outbreaks. the high genetic variability is due to error of RNA-dependent RNA polymerase and also to recombination [4,5]. Great genetic diversity is favored also by co-circulation and co-infection [6]. Recombination plays a key role, since it can lead to forms capable of escaping the immune system, overcoming specific antibody selection in the infected host [7].

\section{Epidemiology}

EVs are among the most common viruses infecting humans and are responsible for an estimated 10 to 15 million cases of symptomatic infections every year in the US [8]. Data from the US show furthermore that children less than one year of age may account for about $40 \%$ of EVs infections in patients with known age [9]. Verboon-Maciolek et al. estimated an incidence of EVs infection in the neonatal period of 26 cases per 100,000 live births in the Netherlands [10].

Non-polio EVs show seasonal patterns of incidence. In temperate areas, EVs are characteristically found in the summer and early autumn, although outbreaks may continue into the winter; in tropical climates, circulation tends to be year-round or associated with the rainy season. In Europe, approximately 50-65\% of infections affecting infants occur from April to October. There are frequent fluctuations in predominant EVs serotypes, with some serotypes showing periods of relative quiescence followed by extensive outbreaks. Variation by location is an important characteristic of EVs epidemiology [11-16]. Table 2 shows the extreme variability of predominant serotypes in neonates and infants according to different studies.

EVs outbreaks may affect small groups or communities (such as schools or hospital wards) or may become widespread at a regional, national, or even international level [17]. Greater genotypic heterogeneity is observed in early infancy, possibly because the immune system is more mature in older children. Echovirus 11 was the most frequent genotype isolated from children under five years of age in northern Italy between 2010 and 2014; Echovirus 11 was associated with severe disease (acute hepatitis, meningitis, acute flaccid paralysis) in $75 \%$ of cases, particularly in neonates [18]. In recent years, authors reported that some European countries are experiencing a rise of Echovirus 30 infections, a serotype that usually causes central nervous system infections, particularly among neonates [19]. 
Table 2. Epidemiology of EVs infection in newborn and infants.

\begin{tabular}{|c|c|c|c|c|c|c|}
\hline Author-Year & $\begin{array}{c}\text { Verboon- } \\
\text { Maciolek-2008 }\end{array}$ & Rodà-2015 & $\begin{array}{l}\text { Cabrerizo- } \\
2015\end{array}$ & Lv-2016 & $\begin{array}{c}\text { Cabrerizo- } \\
2017\end{array}$ & $\begin{array}{l}\text { Kadambari- } \\
2019\end{array}$ \\
\hline Reference & [11] & [12] & [13] & [14] & [15] & [16] \\
\hline Country & Netherlands & Spain & Spain & China & Spain & UK-Ireland \\
\hline $\begin{array}{c}\text { Single } \\
\text { center/multicenter }\end{array}$ & Single centre & Single centre & Multicentre & Single centre & Multicentre & Multicentre \\
\hline Period in study & $\begin{array}{c}\text { Jan 1994-Dec } \\
2016\end{array}$ & $\begin{array}{l}\text { Mar 2010-Dec } \\
2010\end{array}$ & $\begin{array}{c}\text { Jan 2013-Dec } \\
2013\end{array}$ & $\begin{array}{l}\text { Mar 2011-Sep } \\
2012\end{array}$ & $\begin{array}{c}\text { Jan 2010-Dec } \\
2013\end{array}$ & $\begin{array}{c}\text { Jul 2014-Jul } \\
2015\end{array}$ \\
\hline Age at diagnosis (d) & $0-30$ & $0-90$ & $0-30$ & $0-30$ & $0-30$ & 0-90 \\
\hline Inclusion criteria & $\begin{array}{l}\text { EVs confirmed } \\
\text { cases }\end{array}$ & Fever $>38^{\circ} \mathrm{C}$ & $\begin{array}{l}\text { Fever }>38^{\circ} \mathrm{C} \\
\mathrm{ME}, \mathrm{CS}\end{array}$ & Fever $>38^{\circ} \mathrm{C}$ & $\begin{array}{c}\text { Fever }>38^{\circ} \mathrm{C}, \\
\text { ME CS, } \\
\text { HFMD, AE }\end{array}$ & ME \\
\hline positive/tested (\%) & $21 / 21(100)$ & $195 / 699(28)$ & $32 / 84(38)$ & $131 / 334(39)$ & $249 / 1430(17)$ & $668 / 668(100)$ \\
\hline $\mathrm{M} / \mathrm{F}$ & $14 / 7$ & $114 / 81$ & $17 / 15$ & $85 / 46$ & & \\
\hline \multirow{5}{*}{$\begin{array}{l}\text { Predominant } \\
\text { serotypes }(\%)\end{array}$} & CV-B5 (33) & E-5 (21.1) & E-18 (24) & CV-B1 (47) & E-5 & E-9 (20) \\
\hline & E-11 (9.5) & E-11 (11.8) & E-3 (14) & E-30 (35) & E-11 & E-18 (12) \\
\hline & E-6 (9.5) & E-21 (7.2) & E-5 (14) & CV-B3 (10) & CV-B4 & CV-B5 (8) \\
\hline & CV-A9 (9.5) & E-25 (7.2) & CV-B3 (10) & E-16 (4) & & CV-B4 (7) \\
\hline & Other (28.6) & CV-B4 (6.4) & Other (38) & & & E-25 (6) \\
\hline Seasonal Period (\%) & Jun-Oct (62) & Mar-Aug (73) & Apr-Jul (66) & Mar-Aug (100) & Apr-Jun (50) & Summer (ns) \\
\hline
\end{tabular}

EVs spread from person to person by the fecal-oral and by the respiratory routes but indirect transmission may also occur via different routes, including contaminated water, food and fomites [20]. Neonatal EVs infections can be acquired antenatally (transplacentally or via an ascending route), intrapartum (usually with clinical presentation from two to seven days of life) and postnatally (usually by family members but sometimes from healthcare workers) [3,17]. Inadequate hand washing can contribute to the spread of EVs infections in the neonatal intensive care unit (NICU); however, vertically acquired infections are usually more severe than horizontally acquired [21]. A recent study on neonates and young infants in Japan by Izumita reported EVs positive stool samples in $91 \%$ of siblings and $42 \%$ of parents. Most of them (45\% of siblings and $85 \%$ of parents) were asymptomatic [22].

EVs infections may be also transmitted via breast milk although we emphasize the protective role of breast milk against viral infections, particularly in the first year of life. In a prospective study 150 infants were followed during the first year of age; investigators found that EVs infections were less common among those who were exclusively breastfed for at least 2 weeks ( 0.38 vs 0.59 infections per child, $p=0.04)$ [23].

Classically reported risk factors for severe neonatal EVs infections include: preterm birth, maternal viral infections in the peripartum, onset of symptoms in the first week of life, and lack of specific antibodies [24-27]. A retrospective study was carried out in Australia between 2008 and 2012; among 109 cases of EVs meningoencephalitis (all age groups) the higher incidence was found in the pediatric age, particularly under three months of age ( 46 out of 109 cases, $42 \%$ of total cases); among these 46 infants, 26 (56\%) were newborns (under one month of age) and $9(20 \%)$ were preterm born [28].

\section{Pathogenesis}

Following oral or respiratory transmission, EVs reach the pharynx and the alimentary tract and subsequently spread to regional lymphoid tissues (tonsils, Peyer patches, and regional lymph nodes). The viremia occurs in a few days; EVs spread to the reticuloen- 
dothelial system, including liver, spleen, bone marrow and more distant lymph nodes. Host immune responses may limit the viral replication, preventing the spread of infection to other sites (subclinical infection). In contrast, the replication in the reticuloendothelial system may lead to a major, secondary viremia (after 3 to 7 days), which involves the CNS, heart and skin, and overlaps to the onset of symptoms. The viral load in secondary sites usually reduces after approximately seven days. Antibodies are the most important immune defense against EVs infections, and viremia recovers when type-specific neutralizing antibody levels increase [29].

Mutations in the structural region of the capsid, which have been observed in EVs, can alter the antigenicity of each strains and the consequent antibody response, increasing the ability of the virus to evade the immune system $[7,30]$.

Figure 1 details the stages of the pathogenetic process of EVs infection.

\begin{tabular}{|c|c|c|c|c|c|c|c|c|}
\hline Oral or & $\begin{array}{c}\text { Throat and } \\
\text { lower }\end{array}$ & $\begin{array}{c}\text { Direct } \\
\text { spread to }\end{array}$ & $\begin{array}{l}\text { Regional } \\
\text { lymph }\end{array}$ & $\begin{array}{l}\text { Minor } \\
\text { viremia }\end{array}$ & $\begin{array}{l}\text { Liver, } \\
\text { spleen }\end{array}$ & $\begin{array}{l}\text { Major } \\
\text { viremia }\end{array}$ & $\begin{array}{l}\text { Target } \\
\text { organs }\end{array}$ & $\begin{array}{l}\text { Viremia } \\
\text { ceases, }\end{array}$ \\
\hline $\begin{array}{l}\text { respiratory } \\
\text { acquisition }\end{array}$ & $\begin{array}{c}\text { alimentary } \\
\text { tract }\end{array}$ & Day 1 & $\begin{array}{l}\text { nodes, } \\
\text { tonsils, } \\
\text { and Peyer } \\
\text { patches }\end{array}$ & Day 3 & $\begin{array}{l}\text { and } \\
\text { distant } \\
\text { lymph } \\
\text { nodes }\end{array}$ & $\begin{array}{l}\text { Day } \\
\text { 3to } 7\end{array}$ & $\begin{array}{l}\text { such as } \\
\text { CNS, heart, } \\
\text { respiratory } \\
\text { tract, skin }\end{array}$ & $\begin{array}{l}\text { appear } \\
\text { After } \\
\text { Day } 7\end{array}$ \\
\hline
\end{tabular}

Figure 1. Pathogenetic stages of EVs infection [3].

\section{Clinical Findings}

\subsection{Abortion, Stillbirths and Intrauterine Infections}

In a Swedish serological investigation, IgM antibodies against Coxsackievirus group B were found in $42 \%$ of pregnant women with abortion as compared with $18 \%$ of controls [31]. Several case reports describe isolation of EVs from amniotic fluid, often in association with maternal symptoms suggestive of chorioamnionitis and with fetal demise. In some cases, the viral agent has been identified in the myocardium, brain, liver and placenta of stillborn infants [3]. Coxsackievirus infections during pregnancy have been associated with congenital anomalies (such as urogenital anomalies, cardiovascular defects) in serological studies [32].

\subsection{Clinical Manifestations in Neonates and Infants}

The vast majority of EVs infections are asymptomatic and yet may serve as significant sources for spread of infection. The early epidemiological study by Jenista et al. carried out in neonates from birth to day 28 of life found an asymptomatic carriage in $59(79 \%)$ of 75 EVs infected neonates [33]. Symptomatic infections are more common in young children. Clinical manifestations range from minor febrile illness to severe conditions, sometimes fatal. Infections are usually more severe in neonates and young infants, especially under 1 year of age. Neonatal symptoms may occur as early as Day 1 of life, and severe disease usually occurs within the first two weeks of life [34]. Most have a benign course and fever resolves in an average of 3 days while additional symptoms usually recover within one week $[17,35]$. History includes a maternal viral illness preceding or immediately following delivery in approximately $60 \%$ of cases, with fever, respiratory findings, and/or abdominal pain. These symptoms are also commonly found in other family members [36].

Risk factors and clinical features associated with severe disease include absence of neutralizing antibody to the infecting serotype, maternal illness prior to or at delivery, prematurity, onset of illness within the first few days of life, severe hepatitis, multi-organ failure. Severe disease is also associated with specific infecting EVs serotypes (such as Group B coxsackieviruses and echovirus 11) $[26,27,37,38]$. A Chinese systematic review, that includes 66 articles and 237 cases of severe neonatal EVs infections (from 2000 to 2020), reports different rates of hepatitis or coagulopathy $(46 \%)$, myocarditis $(37 \%)$, meningoen- 
cephalitis $(11 \%)$, other complications $(6 \%)$ such as hemophagocytic lymphohistiocytosis and pulmonary hemorrhage [39]. Table 3 reports the incidence of main clinical findings in EVs infected neonates and infants' populations reported in recent literature.

Table 3. Most frequent clinical findings of EVs infection in newborn and infants.

\begin{tabular}{|c|c|c|c|c|c|c|c|c|}
\hline Author (Year) & $\begin{array}{c}\text { Verboon- } \\
\text { Maciolek } \\
(2008)\end{array}$ & $\begin{array}{l}\text { March } \\
(2014)\end{array}$ & $\begin{array}{l}\text { Rodà } \\
\text { (2015) }\end{array}$ & $\begin{array}{c}\text { Lv } \\
(2016)\end{array}$ & $\begin{array}{l}\text { Lafolie } \\
\text { (2018) }\end{array}$ & $\begin{array}{c}\text { Berardi } \\
(2019)\end{array}$ & $\begin{array}{c}\text { Kadambari } \\
\text { (2019) }\end{array}$ & $\begin{array}{l}\text { Chen } \\
(2021)\end{array}$ \\
\hline Reference & [11] & [28] & [12] & [14] & [40] & [41] & [16] & [42] \\
\hline Age at diagnosis (d) & $0-30$ & $0-30$ & 0-90 & $0-30$ & $0-30$ & 0-90 & $0-90$ & $0-30$ \\
\hline Inclusion criteria & $\begin{array}{c}\text { EVs } \\
\text { confirmed } \\
\text { cases }\end{array}$ & $\begin{array}{l}\text { Positive } \\
\text { CSF PCR }\end{array}$ & $\begin{array}{c}\text { Fever }> \\
38^{\circ} \mathrm{C}\end{array}$ & $\begin{array}{c}\text { Fever }> \\
38^{\circ} \mathrm{C}\end{array}$ & $\begin{array}{c}\text { Fever }>38{ }^{\circ} \mathrm{C}, \\
\mathrm{CS}, \text { suspected } \\
\text { ME }\end{array}$ & $\begin{array}{l}\text { Positive } \\
\text { plasma or } \\
\text { CSF PCR }\end{array}$ & ME & $\begin{array}{c}\text { Positive } \\
\text { throat swab } \\
\text { or CSF PCR }\end{array}$ \\
\hline \multicolumn{9}{|c|}{ Symptoms } \\
\hline Fever (\%) & 76 & 83 & 100 & 100 & 100 & 81.8 & 85 & 100 \\
\hline Poor feeding (\%) & ns & 40 & ns & 16.8 & 28 & 31.8 & 54 & ns \\
\hline GI symptoms (\%) & 52 & ns & 37.5 & 52.6 & 10 & 29.5 & ns & 0 \\
\hline $\begin{array}{c}\text { Respiratory } \\
\text { symptoms (\%) }\end{array}$ & 52 & ns & 21.1 & 36.6 & 14 & ns & 12 & 0 \\
\hline Irritability (\%) & 38 & 40 & 26.3 & 13.7 & 62 & 59.1 & 66 & 26 \\
\hline Lethargy (\%) & ns & ns & ns & 2.3 & ns & ns & 36 & 0 \\
\hline Rash (\%) & 23 & 17 & 13.2 & 26 & 6 & 2.3 & 24 & 39.1 \\
\hline Seizure (\%) & 42 & 2.2 & ns & 1.5 & 0 & 6.8 & ns & 0 \\
\hline
\end{tabular}

\subsubsection{Mild, Nonspecific Febrile Illness and Sepsis-like Illness}

Nonspecific febrile illness is the most common finding in EVs infections. Fever occurs in most neonates (76 to $100 \%$ ), sometimes with a biphasic pattern, and may last from 1 to 5 days (usually $3-4$ days) [24]. A retrospective study conducted in Taiwan on a population of 146 young infants $<3$ months of age with EVs infection reports non-specific febrile illness as the final diagnosis in approximately $30 \%$ of cases [38]. A prospective study carried out on a population of 353 infants $<90$ days with sepsis-like symptoms identified EVs as the causative agent in $132(37 \%)$ of cases [43]. Febrile illness may sometimes present with alarming symptoms, which must be differentiated from sepsis or bacterial meningitis. The disease usually begins abruptly with fever (ranging from $38^{\circ} \mathrm{C}$ to $39^{\circ} \mathrm{C}$ or higher), malaise, irritability, poor feeding, lethargy, diarrhea and/or vomiting. In addition, a rash, highly variable in nature, but usually macular or maculo-papular, is frequently present.

\subsubsection{Central Nervous System Involvement}

Neonates show a higher risk of severe systemic illness, meningitis and meningoencephalitis. EVs meningitis is almost three-fold more frequent than bacterial meningitis and the estimated incidence in high-income countries is 12-19 cases per 100,000 population per year $[44,45]$. Non-polio EVs are the leading cause of viral meningitis, accounting for 85 to $95 \%$ of the cases in which an etiologic agent is identified [46-48]. Kadambari and colleagues found that EVs were responsible for the vast majority of meningoencephalitis reported in the UK and Ireland in infants aged less than 3 months with an estimated incidence of 79 cases /100,000 live births per year [16].

The term aseptic meningitis refers to a clinical syndrome of meningeal inflammation in which common bacterial agents cannot be identified in the cerebrospinal fluid (CSF). The initial clinical findings in neonatal meningitis are similar to those in sepsis-like illness. CSF 
often shows pleocytosis (frequently $<500$ but occasionally higher than $1000 \mathrm{WBCs} / \mu \mathrm{L}$ ); polymorphonuclear cells are often predominant in the first $48 \mathrm{~h}$ before becoming mostly mononuclear [49-51]. Cerebrospinal fluid can have normal parameters despite positive viral culture or PCR results, particularly in the first few months of life and early after illness onset. Wide variations in all parameters, however, are the rule, even during an epidemic involving a single serotype. Therefore, initial CSF parameters may not be helpful in ruling out bacterial infections of the central nervous system or confirming a viral etiology.

EVs are responsible for 10-20\% of encephalitis with an identified cause [52]. Encephalitis with parenchymal brain involvement is less frequent than meningitis. Encephalitis is suggested by extreme lethargy that may progress to altered levels of consciousness. Seizures may occur and a bulging fontanelle may sometimes be evident. Up to $40 \%$ of cases may present with focal findings (seizures, myoclonus and hemichorea), whereas MRI study confirms the white matter damage [39,53-55].

\subsubsection{Cardiac Involvement}

Myocarditis is an inflammation of the myocardium associated with damage that is unrelated to an ischemic injury. EVs account for approximately $25-35 \%$ of cases of myocarditis and pericarditis with proven cause. Group B coxsackieviruses are the predominant causative agents of acute EVs myocarditis (specially CVB 1-5), although Coxsackie A and echoviruses also may be causative [56,57]. However, only a very small proportion of EVs infections result in overt cardiac involvement.

EVs damage the heart primarily via direct lysis of infected myocytes, but immunemediated mechanisms may also play a role. Neonatal EVs myocarditis may present abruptly with arrhythmias, congestive heart failure and cardiogenic shock and can lead to multi organ failure. Fever, malaise, and anorexia are frequently part of the initial clinical presentation. Furthermore, many patients show signs of respiratory distress and cyanosis. Cardiac findings normally include transitory systolic murmur and electrocardiographic changes (such as supraventricular tachycardia, ST segment depression, and T wave abnormalities). Echocardiography shows cardiomegaly, reduced contractility, low ejection fraction, and sometimes pericardial effusion. Myocardial enzyme serum concentration may be raised. Chest radiography often demonstrates cardiac enlargement [27,58].

Myocarditis is often accompanied by disseminated viral infection involving the central nervous system, liver, pancreas and adrenal glands. Mortality may be as high as $30-50 \%$ [39]. EVs myocarditis may lead to cardiovascular collapse refractory to conventional resuscitation measures. When cardiovascular failure is present, progression is usually rapid, often within two days from the onset of illness $[59,60]$. However, in approximately a third of patients, cardiovascular collapse may occur several days after the onset of EVs infection. In a few cases, neonates critically ill with EVs myocarditis have been supported with extracorporeal membrane oxygenation (ECMO) as a bridge to cardiopulmonary recovery [61].

\subsubsection{Gastrointestinal Manifestations and Acute Hepatitis}

Gastrointestinal signs and symptoms are frequently present, but they are rarely isolated. Among 27 neonates with EVs infection, vomiting, abdominal distension and diarrhoea were reported in 33\%,70\% and $81 \%$ of cases, respectively. Moreover, three of 27 had necrotizing enterocolitis [27].

Acute hepatitis and coagulopathy are serious manifestations of neonatal infections, often associated with Echovirus infections (types 5, 11, 6, 7, 9, 14, 17,19, 21) and Coxsackievirus B infections $[62,63]$. Findings that are commonly related to this condition include hepatomegaly, jaundice and laboratory abnormalities, such as coagulopathy, elevated transaminases, and hyperbilirubinemia. Coagulopathy is characterized by thrombocytopenia, clotting time prolongation, fibrin split products and bleeding diathesis. Acute hepatic necrosis and liver failure may complicate the course [64]. Among 42 cases of EVs hepatitis and coagulopathy, a fatal outcome was reported in $10(24 \%)$ cases. Most signifi- 
cant factors associated with mortality were higher total bilirubin levels and a concomitant myocarditis [38].

\subsubsection{Respiratory Illnesses}

Respiratory manifestations are usually overshadowed by other clinical findings of neonatal EVs infections. Morens and colleagues report only $7 \%$ of $338 \mathrm{EVs}$ infections in infants less than two months of age classified as respiratory illnesses [24]. Respiratory symptoms that may be observed in neonatal EVs infections are cough, wheezing, rhinorrhea, tachypnea [17]. Clusters of severe respiratory disease have been observed with multiple lineages of enterovirus D68 [65,66]. Rare respiratory complications of neonatal EVs infections are pulmonary hemorrhage, persistent pulmonary hypertension; is also described a case of pulmonary hypoplasia in a 38 weeks gestational age newborn with a vertical infection by Echovirus 11 [39]. Life-threatening pulmonary edema, hemorrhage, and interstitial pneumonitis may complicate encephalitis caused by EV-A71 [67-69].

\subsubsection{Exanthems and Hand-Foot-Mouth Disease}

Infants with EVs infections can develop skin lesions which are usually macular or maculopapular eruptions, but petechial lesions occasionally occur. Rashes have occurred with many serotypes, such as coxsackieviruses B1, B3 and B5, and echoviruses 4, 5, 6, 9, $11,16,17,18$, and 21 [35]. Of 27 infants studied by Lake, $41 \%$ had rash [34]. Abzug and colleagues reported $38 \%$ of 29 neonates aged 0 to 14 days with EV infection had rashes [36].

Hand-foot-and-mouth disease (HFMD) is a common rash syndrome, caused by human enterovirus species A (HEV-A). The most important serotypes are coxsackievirus A16 and EV-A71 [70,71]. Scattered vesicular lesions occur in the posterior pharynx, the buccal mucosa, tongue, palate, gingiva and lips; these vesicles ulcerate readily, leaving shallow lesions with red areolae. Frequently also appear sparse grayish maculopapular or pustular vesicles ( 3 to $5 \mathrm{~mm}$ in diameter, surrounded by erythematous areolae) on the dorsum of the fingers, particularly in periungual areas, and on the margins of heels. Lesions on the palms, soles of the feet, buttocks, groin, and sometimes knees and elbows may appear occasionally [72]. Xu reported 16 cases of neonatal HFMD with coxsackievirus A6 infection between 2016 and 2017 in Shanghai, China [73].

\section{Diagnosis}

A specific diagnosis of EVs infections implicates detection of the virus in biological samples. Confirmation of the diagnosis can be important in reducing hospitalization, inappropriate antibiotic use, and additional diagnostic testing often performed to rule out other conditions [74-77]. Because speed, specific and sensitive, amplification of viral RNA through reverse transcription polymerase chain reaction (RT-PCR) has already replaced viral isolation in cell culture. RT-PCR for primary diagnosis targets the $5^{\prime}$ untranslated region (5'UTR) [78].

RT-PCR is proven to be useful in the identification of EVs in CSF, plasma, throat, tracheal, rectal, stool, and urine specimens. By using blood and CSF RT-PCR, more than $25 \%$ of infants admitted to the hospital for suspected sepsis over a year period tested EVs positive [79]. Therefore, the workup for febrile neonates admitted to hospital for suspected sepsis or meningitis should include EVs RT-PCR testing in blood and CSF samples. A recent prospective study was conducted in newborn, infants and children to assess the sensitivity of blood EVs RT-PCR test in the workup of fever without source, sepsis-like illness and suspected meningitis. Among 71 EVs infected neonates, RT-PCR confirmed EVs more commonly in plasma ( $99 \%$ of cases) with respect to CSF samples ( $87 \%$ of cases, $p=0.01$ ) [40]. Among 128 infants aged 0 to 90 days who underwent sepsis evaluation, the duration of empiric antibiotic treatment was significantly reduced by the use of EVs RT-PCR. EVs positive infants showed a shorter duration of empiric antibiotic therapy compared to EVs negative patients (median duration $18 \mathrm{~h}$ vs $48 \mathrm{~h}, p<0.0001$ ) and EVs RT-PCR untested patients (median of $18 \mathrm{~h}$ vs $48 \mathrm{~h}, p<0.001$ ) [80]. Moreover, investigators 
from the European Non-Polio Enterovirus Network recommend collecting respiratory and stool samples in suspected CNS EVs infection [81].

RT-PCR represents a valuable diagnostic tool but requires expensive instrumentation not available in all facilities. Recently, Daskou and colleagues developed a colorimetric loopmediated isothermal amplification (LAMP) assay, which demonstrated high sensitivity and specificity, with the advantage of faster time and lower costs in comparison to PCR [82].

The gold standard for EVs typing is represented by sequencing of the VP1 capsid protein gene. Sequencing multiple parts of the full-length genome is used to identify the emergence of recombinant EVs variants [81]. From a future perspective, a promising technique is represented by metagenomic next-generation sequencing, which offers multiple advantages including the identification of virulence determinants and the prediction of resistance to antivirals [83].

Serologic methods implicate the detection of a rise in antibody titers after infection.

Nevertheless, the need of collecting both an acute and a convalescent serum specimen makes serologic diagnosis impractical and time consuming in the clinical setting [3].

Further potentially severe viral or bacterial infections should be ruled out. When plasma or CSF test EVs RT-PCR positive a concomitant bacterial infection is unlikely. In a recent prospective multicentre study only $6 \%$ (22 of 360) of neonates and children with EVs meningitis or sepsis were found to have concomitant bacterial infection. Most of them had a urinary tract infection and none had a bacterial sepsis or meningitis [40]. This findings was consistent with previous studies $[79,84,85]$. Therefore, empiric antibiotic treatment may be discontinued in most cases when EVs is confirmed in samples [86].

Human parechoviruses must be considered in the differential diagnosis of EVs infection because they are recognized as an important cause of disease in neonates and infants with a similar clinical spectrum. Since they represent a distinct genus, a specific PCR assay must be performed to identify parechovirus infections $[87,88]$.

\section{Complications and Outcome}

The outcome of EVs infections is usually excellent, although in early studies case fatalities reached up to $80 \%$ [26]. In the previously mentioned systematic review by Zhang concerning life-threatening infection in neonates, investigators reported a case-fatality rate of approximately $30 \%$. Morbidity and mortality were often associated with myocarditis and liver involvement in neonates or immunocompromised children [39].

Hepatic, cardiac or neurologic sequelae may occur after EVs infections. Hepatic injury may last up to infancy, although improvement usually occurs in surviving infants. Severe hepatitis can lead to cirrhosis and chronic hepatic failure.

The overall acute mortality after EVs myocarditis may reach $4 \%$. In most cases, a full recovery usually occurs after months. Nevertheless, heart sequelae (chronic dilated cardiomyopathy, calcific myocarditis, ventricular micro-aneurysms, chronic heart failure, dysrhythmias, or constrictive pericarditis) may sometimes occur [58,61].

Some studies on the outcome of central nervous system infection have reported longterm morbidity, including spasticity, hypotonicity, motor weakness, intellectual deficits, seizure disorders, hydrocephaly, microcephaly, ocular abnormalities and delayed speech and language development $[52,89]$. Nevertheless, there are a lack of large studies detailing the neurodevelopmental outcome of EVs infections.

\section{Treatment}

Potential antiviral drugs that target various stages of the viral replication cycle are currently being evaluated in-vitro and in animal models. In some cases, Phase I and II in humans have been carried out.

At present, the most advanced antiviral treatment relies on two antiviral agents (Pleconaril and Pocapavir). Both integrate into the capsid and inhibit viral attachment and uncoating. A recent systematic review evaluated 66 studies concerning neonatal severe 
EVs infections. Pleconaril and Pocapavir were administered in 5.9\% and $1.3 \%$ of 237 severe infections, respectively [39].

Pleconaril is at present one of the most studied antiviral treatment for severe EVs infections in neonates. A recent double-blind placebo-controlled study enrolled 61 neonates with suspected or proven EVs infection aged less than 2 weeks, of which 43 received Pleconaril and 18 were given placebo. However, the study failed to demonstrate a faster viral clearance after treatment as compared to untreated neonates and no increase of survival was demonstrated, although adverse events were rare [90].

In-vitro tests show that Pocapavir (V-073) has antiviral activity against some clinical isolates of non-polio EVs. However, Pocapavir has been administered in only four neonates. The first report concerns a neonate with coagulopathy, cardiopulmonary failure and coxsackievirus B3 infection. The newborn improved after treatment without any apparent adverse effects [91]. The second study reports the use of Pocapavir and intravenous immunoglobulins (IVIG) in a late preterm female presenting at 14 days of life with EVs myocarditis and hepatitis. The neonate had improved liver function after antiviral treatment, despite persistence of a dilated cardiomyopathy [92]. Finally, Pocapavir use was reported in two monochorionic diamniotic twins who both presented with EVs myocarditis and cardiogenic shock on Day 12 of life. The patients in this report gradually improved and showed no adverse effect related to Pocapavir administration. Nevertheless, the contribution of each intervention is difficult to assess since they both required ECMO and received IVIG prior to Pocapavir treatment [93].

Additional treatments have been tested in animal models and in-vitro [94]. Alpha interferon, lactoferrin and ribavirin have shown antiviral activity against EV-A71, although there are no studies on neonates. Among them, ribavirin also plays an important role in studies concerning the evolution of EVs under strong mutagenic pressure, with potential implications for the development of new vaccines. In fact, restricting the quasispecies diversity of a viral population provides a new approach to engineering live attenuated vaccines for RNA viruses and ribavirin represents a tool to isolate high-fidelity variants of EVs $[95,96]$.

Antibodies are a key host defense against EVs infections and IVIG contain variable amounts of neutralizing antibodies to EVs. Therefore, IVIG are sometimes administered for treating severe EVs infections, although evidence of their effectiveness is poor. Abzug and colleagues carried out a randomized clinical trial and IVIG were administered to 9 of 16 neonates. Treated neonates had a faster clearance of viremia and viruria, but the study was too small to demonstrate any significant effect on clinical outcomes [97]. A retrospective study investigated 41 neonates with severe EVs hepatitis and coagulopathy treated with IVIG. The rate of survival was high (93\%) when IVIG were given within 3 days from the onset of symptoms. However, neonates were not randomized making it difficult to compare early and late treatments [98].

Overall, at present there is a lack of strong evidence to support antiviral treatments or IVIG in neonates. Most studies enroll very few neonates or are single case reports. Therefore, in a clinical setting, the only treatment is mainly supportive. Careful clinical surveillance is important since neonates may worsen after 2 or 3 days from the onset of symptoms.

\section{Prevention Strategies}

Standard hygiene measures, particularly hand washing, play an important role in preventing nosocomial transmission of EVs infections. Cohorting is effective in controlling virus spread when outbreaks occur within the nursery or the NICU [99].

Enterovirus A71 is the main causative agents of HFMD and large outbreaks caused by EV-A71, especially in the Asia-Pacific region, may sometimes lead to severe acute neurologic disease (such as encephalitis, acute flaccid paralysis and polio-like syndrome) and life-threatening cardiopulmonary failures $[71,100,101]$. Due to the socioeconomic impact of EV-A71 infection, great interest has been directed towards the development of an 
effective vaccine. Five formalin-inactivated EV-A71 vaccines, evaluated in human clinical trials in China, Taiwan, and Singapore, were found to be safe and to stimulate strong neutralizing antibody responses against EV-A71 [102-104]. A Phase IV study was carried out in over 150,000 children. The incidence of EV-A71 infection decreased after vaccine administration. Nearly $90 \%$ of hand foot and mouth diseases and infection-associated hospital admissions were prevented, especially among children aged 6 to 35 months [105].

\section{Conclusions}

EVs infections are common in children. Given the extreme variability of predominant serotypes in different geographical areas and in different years, a close molecular epidemiological surveillance would be desirable, in order to control the spread of new outbreaks through appropriate preventive measures. Infections can be severe, especially in the first days of life, and may lead to death, long-term sequelae, and neurodevelopmental delay. Currently, the treatment of severe infections is mainly supportive, given the lack of strong evidence on the use of antivirals or IVIG. In milder cases, the impact on neurodevelopmental outcome is less clear, due to the lack of prospective studies in large populations.

Author Contributions: Conceptualization, M.S., L.C., C.T. and A.B. (Alessandra Boncompagni); methodology, A.B. (Alessandra Boncompagni) and A.B. (Alberto Berardi); validation, L.I. and A.B. (Alessandra Boncompagni); writing-original draft preparation, M.S., L.C., C.T., L.L. and A.B. (Alberto Berardi); writing-review and editing, M.S., L.C., C.T., A.B. (Alessandra Boncompagni) and A.B. (Alberto Berardi); visualization, C.R., I.G., E.G.; supervision, C.R., I.G., E.G., L.I., L.L. and A.B. (Alberto Berardi); All authors have read and agreed to the published version of the manuscript.

Funding: This research received no external funding.

Conflicts of Interest: The authors declare no conflict of interest.

\section{References}

1. Gorbalenya, A.E. Available online: Https://Talk.Ictvonline.Org/Ictv-Reports/Ictv_online_report/Positive-Sense-Rna-Viruses / w / Picornaviridae (accessed on 30 October 2021).

2. Pirbright Institute. Available online: Https:/ Www.Picornaviridae.Com (accessed on 30 October 2021).

3. Cherry, J.D.; Krogstad, P. Enterovirus, Parechovirus and Saffold Virus Infections. In Remington and Klein's Infectious Diseases of the Fetus and Newborn Infant; Elsevier Health Sciences: Amsterdam, The Netherlands, 2015; ISBN 978-0-323-24147-2.

4. Freistadt, M.S.; A Vaccaro, J.; E Eberle, K. Biochemical characterization of the fidelity of poliovirus RNA-dependent RNA polymerase. Virol. J. 2007, 4, 44. [CrossRef]

5. Simon-Loriere, E.; Holmes, E.C. Why do RNA viruses recombine? Nat. Rev. Genet. 2011, 9, 617-626. [CrossRef]

6. Muslin, C.; Mac Kain, A.; Bessaud, M.; Blondel, B.; Delpeyroux, F. Recombination in Enteroviruses, a Multi-Step Modular Evolutionary Process. Viruses 2019, 11, 859. [CrossRef]

7. Nikolaidis, M.; Mimouli, K.; Kyriakopoulou, Z.; Tsimpidis, M.; Tsakogiannis, D.; Markoulatos, P.; Amoutzias, G.D. Large-scale genomic analysis reveals recurrent patterns of intertypic recombination in human enteroviruses. Virology 2018, 526, 72-80. [CrossRef]

8. Khetsuriani, N.; LaMonte, A.; Oberste, M.S.; Pallansch, M.A. Enterovirus Surveillance-United States, 1970-2005. Available online: https:/ / www.cdc.gov/mmwr/preview/mmwrhtml/ss5508a1.htm (accessed on 22 March 2017).

9. Abedi, G.R. Enterovirus and Human Parechovirus Surveillance-United States, 2009-2013. Morb. Mortal. Wkly. Rep. 2015, 64, 940-943. [CrossRef]

10. Verboon-Maciolek, M.; Krediet, T.; van Loon, A.; Kaan, J.; Galama, J.; Gerards, L.; Fleer, A. Epidemiological survey of neonatal non-polio enterovirus infection in the Netherlands. J. Med. Virol. 2001, 66, 241-245. [CrossRef] [PubMed]

11. Verboon-Maciolek, M.A.; Krediet, T.G.; Gerards, L.J.; de Vries, L.S.; Groenendaal, F.; van Loon, A.M. Severe Neonatal Parechovirus Infection and Similarity with Enterovirus Infection. Pediatr. Infect. Dis. J. 2008, 27, 241-245. [CrossRef]

12. Roda, D.; Pérez-Martínez, E.; Cabrerizo, M.; Trallero, G.; Martínez-Planas, A.; Luaces, C.; García-García, J.-J.; Muñoz-Almagro, C.; Launes, C. Clinical characteristics and molecular epidemiology of Enterovirus infection in infants $<3$ months in a referral paediatric hospital of Barcelona. Eur. J. Nucl. Med. Mol. Imaging 2015, 174, 1549-1553. [CrossRef]

13. Cabrerizo, M.; Trallero, G.; Pena, M.J.; Cilla, A.; Megias, G.; Muñoz-Almagro, C.; Del Amo, E.; Roda, D.; Mensalvas, A.I.; Moreno-Docón, A.; et al. Comparison of epidemiology and clinical characteristics of infections by human parechovirus vs. those by enterovirus during the first month of life. Eur. J. Nucl. Med. Mol. Imaging 2015, 174, 1511-1516. [CrossRef] [PubMed] 
14. Lv, X.; Qian, L.; Wu, T.; Yuan, T. Enterovirus infection in febrile neonates: A hospital-based prospective cohort study. J. Paediatr. Child Health 2016, 52, 837-841. [CrossRef]

15. Cabrerizo, M.; Díaz-Cerio, M.; Muñoz-Almagro, C.; Rabella, N.; Tarragó, D.; Romero, M.P.; Pena, M.J.; Calvo, C.; Rey-Cao, S.; Moreno-Docón, A.; et al. Molecular epidemiology of enterovirus and parechovirus infections according to patient age over a 4-year period in Spain. J. Med. Virol. 2017, 89, 435-442. [CrossRef] [PubMed]

16. Kadambari, S.; Braccio, S.; Ribeiro, S.; Allen, D.J.; Pebody, R.; Brown, D.; Cunney, R.; Sharland, M.; Ladhani, S. Enterovirus and parechovirus meningitis in infants younger than 90 days old in the UK and Republic of Ireland: A British Paediatric Surveillance Unit study. Arch. Dis. Child. 2018, 104, 552-557. [CrossRef] [PubMed]

17. Harik, N.; DeBiasi, R.L. Neonatal nonpolio enterovirus and parechovirus infections. Semin. Perinatol. 2018, 42, 191-197. [CrossRef]

18. Bubba, L.; Martinelli, M.; Pellegrinelli, L.; Primache, V.; Tanzi, E.; Pariani, E.; Binda, S. A 4-year Study on Epidemiologic and Molecular Characteristics of Human Parechoviruses and Enteroviruses Circulating in Children Younger Than 5 Years in Northern Italy. Pediatr. Infect. Dis. J. 2017, 36, 13-19. [CrossRef]

19. Broberg, E.K.; Simone, B.; Jansa, J.; Contributors, T.E.M.S. Upsurge in echovirus 30 detections in five EU/EEA countries, April to September, 2018. Eurosurveillance 2018, 23, 1800537. [CrossRef]

20. Dunn, J.J. Enteroviruses and Parechoviruses. In Diagnostic Microbiology of the Immunocompromised Host, 2nd ed.; Hayden, R.T., Wolk, D.M., Carroll, K.C., Tang, Y.-W., Eds.; American Society for Microbiology: Washington DC, USA; pp. 273-296; ISBN 978-1-55581-903-3.

21. Tebruegge, M.; Curtis, N. Enterovirus infections in neonates. Semin. Fetal Neonatal Med. 2009, 14, 222-227. [CrossRef] [PubMed]

22. Izumita, R.; Deuchi, K.; Aizawa, Y.; Habuka, R.; Watanabe, K.; Otsuka, T.; Saitoh, A. Intrafamilial Transmission of Parechovirus A and Enteroviruses in Neonates and Young Infants. J. Pediatr. Infect. Dis. Soc. 2018, 8, 501-506. [CrossRef] [PubMed]

23. Sadeharju, K.; Knip, M.; Virtanen, S.M.; Savilahti, E.; Tauriainen, S.; Koskela, P.; Akerblom, H.K.; Hyoty, H.; the Finnish TRIGR Study Group. Maternal Antibodies in Breast Milk Protect the Child from Enterovirus Infections. Pediatrics 2007, 119, 941-946. [CrossRef] [PubMed]

24. Morens, D.M. Enteroviral disease in early infancy. J. Pediatr. 1978, 92, 374-377. [CrossRef]

25. Dagan, R. Nonpolio enteroviruses and the febrile young infant: Epidemiologic, clinical and diagnostic aspects. Pediatr. Infect. Dis. J. 1996, 15, 67-71. [CrossRef]

26. Abzug, M.J. Presentation, Diagnosis, and Management of Enterovirus Infections in Neonates. Pediatr. Drugs 2004, 6, 1-10. [CrossRef]

27. Chuang, Y.-Y.; Huang, Y.-C. Enteroviral infection in neonates. J. Microbiol. Immunol. Infect. 2019, 52, 851-857. [CrossRef]

28. March, B.; Eastwood, K.; Wright, I.; Tilbrook, L.; Durrheim, D.N. Epidemiology of enteroviral meningoencephalitis in neonates and young infants. J. Paediatr. Child Health 2013, 50, 216-220. [CrossRef]

29. Muehlenbachs, A.; Bhatnagar, J.; Zaki, S.R. Tissue tropism, pathology and pathogenesis of enterovirus infection. J. Pathol. 2014, 235, 217-228. [CrossRef]

30. Fikatas, A.; Dimitriou, T.; Kyriakopoulou, Z.; Tsachouridou, O.; Gartzonika, C.; Levidiotou-Stefanou, S.; Amoutzias, G.D.; Markoulatos, P. Serum Neutralization Assay for the Determination of Antibody Levels Against Non-Polio Enterovirus Strains in Central and Western Greece. Viral Immunol. 2016, 29, 444-450. [CrossRef] [PubMed]

31. Axelsson, C.; Bondestam, K.; Frisk, G.; Bergström, S.; Diderholm, H. Coxsackie B virus infections in women with miscarriage. J. Med. Virol. 1993, 39, 282-285. [CrossRef]

32. Brown, G.C.; Karunas, R.S. Relationship of Congenital Anomalies and Maternal Infection with Selected Enteroviruses1. Am. J. Epidemiol. 1972, 95, 207-217. [CrossRef] [PubMed]

33. Jenista, J.A.; Powell, K.R.; Menegus, M.A. Epidemiology of neonatal enterovirus infection. J. Pediatr. 1984, 104, 685-690. [CrossRef]

34. Lake, A.M.; Lauer, B.A.; Clark, J.C.; Wesenberg, R.L.; McIntosh, K. Enterovirus infections in neonates. J. Pediatr. 1976, 89, 787-791. [CrossRef]

35. Kaplan, M.H.; Klein, S.W.; McPhee, J.; Harper, R.G. Group B Coxsackievirus Infections in Infants Younger than Three Months of Age: A Serious Childhood Illness. Clin. Infect. Dis. 1983, 5, 1019-1032. [CrossRef]

36. Abzug, M.J.; Levin, M.J.; Rotbart, H.A. Profile of enterovirus disease in the first two weeks of life. Pediatr. Infect. Dis. J. 1993, 12, 820-823. [CrossRef] [PubMed]

37. De Graaf, H.; Pelosi, E.; Cooper, A.; Pappachan, J.; Sykes, K.; MacIntosh, I.; Gbesemete, D.; Clark, T.W.; Patel, S.V.; Faust, S.N.; et al. Severe Enterovirus Infections in Hospitalized Children in the South of England. Pediatr. Infect. Dis. J. 2016, 35, 723-727. [CrossRef]

38. Lin, T.-Y.; Kao, H.-T.; Hsieh, S.-H.; Huang, Y.-C.; Chiu, C.-H.; Chou, Y.-H.; Yang, P.-H.; Lin, R.-I.; Tsao, K.-C.; Hsu, K.-H.; et al. Neonatal enterovirus infections: Emphasis on risk factors of severe and fatal infections. Pediatr. Infect. Dis. J. 2003, 22, 889-895. [CrossRef] [PubMed]

39. Zhang, M.; Wang, H.; Tang, J.; He, Y.; Xiong, T.; Li, W.; Qu, Y.; Mu, D. Clinical characteristics of severe neonatal enterovirus infection: A systematic review. BMC Pediatr. 2021, 21, 1-12. [CrossRef]

40. Lafolie, J.; Labbé, A.; L'Honneur, A.S.; Madhi, F.; Pereira, B.; Decobert, M.; Adam, M.N.; Gouraud, F.; Faibis, F.; Arditty, F.; et al. Assessment of blood enterovirus PCR testing in paediatric populations with fever without source, sepsis-like disease, or suspected meningitis: A prospective, multicentre, observational cohort study. Lancet Infect. Dis. 2018, 18, 1385-1396. [CrossRef] 
41. Berardi, A.; Sandoni, M.; Toffoli, C.; Boncompagni, A.; Gennari, W.; Bergamini, M.B.; Lucaccioni, L.; Iughetti, L. Clinical characterization of neonatal and pediatric enteroviral infections: An Italian single center study. Ital. J. Pediatr. 2019, 45, 1-8. [CrossRef] [PubMed]

42. Chen, W.; Dai, S.; Xu, L. Clinical characterization of benign enterovirus infection in neonates. Medicine 2021, 100 , e25706. [CrossRef] [PubMed]

43. De Jong, E.P.; van den Beuken, M.G.A.; van Elzakker, E.P.M.; Wolthers, K.C.; Sprij, A.J.; Lopriore, E.; Walther, F.; Brus, F. Epidemiology of Sepsis-like Illness in Young Infants. Pediatr. Infect. Dis. J. 2018, 37, 113-118. [CrossRef]

44. Michos, A.G.; Syriopoulou, V.P.; Hadjichristodoulou, C.; Daikos, G.L.; Lagona, E.; Douridas, P.; Mostrou, G.; Theodoridou, M. Aseptic Meningitis in Children: Analysis of 506 Cases. PLoS ONE 2007, 2, e674. [CrossRef]

45. Rudolph, H.; Schroten, H.; Tenenbaum, T. Enterovirus Infections of the Central Nervous System in Children. Pediatr. Infect. Dis. J. 2016, 35, 567-569. [CrossRef]

46. Petel, D.; Barton, M.; Renaud, C.; Ouchenir, L.; Brophy, J.; Bowes, J.; Khan, S.; Bitnun, A.; McDonald, J.; Boisvert, A.-A.; et al. Enteroviral and herpes simplex virus central nervous system infections in infants $<90$ days old: A Paediatric Investigators' Collaborative Network on Infections in Canada (PICNIC) study. BMC Pediatr. 2020, 20, 1-10. [CrossRef]

47. Dalwai, A.; Ahmad, S.; Al-Nakib, W. Echoviruses are a major cause of aseptic meningitis in infants and young children in Kuwait. Virol. J. 2010, 7, 236. [CrossRef] [PubMed]

48. Nougairede, A.; Bessaud, M.; Thiberville, S.-D.; Piorkowski, G.; Ninove, L.; Zandotti, C.; Charrel, R.; Guilhem, N.; de Lamballerie, $X$. Widespread circulation of a new echovirus 30 variant causing aseptic meningitis and non-specific viral illness, South-East France, 2013. J. Clin. Virol. 2014, 61, 118-124. [CrossRef]

49. Hysinger, E.B.; Mainthia, R.; Fleming, A. Enterovirus Meningitis with Marked Pleocytosis. Hosp. Pediatr. 2012, 2, 173-176. [CrossRef] [PubMed]

50. Yun, K.W.; Choi, E.H.; Cheon, D.S.; Lee, J.; Choi, C.W.; Hwang, H.; Kim, B.I.; Park, K.U.; Park, S.S.; Lee, H.J. Enteroviral meningitis without pleocytosis in children. Arch. Dis. Child. 2012, 97, 874-878. [CrossRef]

51. Irani, D.N. Aseptic Meningitis and Viral Myelitis. Neurol. Clin. 2008, 26, 635-655. [CrossRef] [PubMed]

52. Pillai, S.C.; Hacohen, Y.; Tantsis, E.; Prelog, K.; Merheb, V.; Kesson, A.; Barnes, E.; Gill, D.; Webster, R.; Menezes, M.; et al. Infectious and Autoantibody-Associated Encephalitis: Clinical Features and Long-term Outcome. Pediatrics 2015, 135, e974-e984. [CrossRef] [PubMed]

53. Verboon-Maciolek, M.A.; Groenendaal, F.; Cowan, F.; Govaert, P.; van Loon, A.M.; de Vries, L.S. White matter damage in neonatal enterovirus meningoencephalitis. Neurology 2006, 66, 1267-1269. [CrossRef]

54. Haddad, J.; Messer, J.; Gut, J.; Chaigne, D.; Christmann, D.; Willard, D. Neonatal Echovirus Encephalitis with White Matter Necrosis. Neuropediatrics 1990, 21, 215-217. [CrossRef]

55. Venkatesan, A.; Tunkel, A.R.; Bloch, K.C.; Lauring, A.S.; Sejvar, J.; Bitnun, A.; Stahl, J.-P.; Mailles, A.; Drebot, M.; Rupprecht, C.E.; et al. Case Definitions, Diagnostic Algorithms, and Priorities in Encephalitis: Consensus Statement of the International Encephalitis Consortium. Clin. Infect. Dis. 2013, 57, 1114-1128. [CrossRef]

56. Barson, W.J.; Craenen, J.; Hosier, D.M.; Brawley, R.L.; Hilty, M.D. Survival Following Myocarditis and Myocardial Calcification Associated with Infection by Coxsackie Virus B-4. Pediatrics 1981, 68, 79-81. [CrossRef] [PubMed]

57. Drew, J.H. Echo 11 Virus Outbreak in a Nursery Associated with Myocarditis. J. Paediatr. Child Health 1973, 9, 90-95. [CrossRef]

58. Freund, M.W.; Kleinveld, G.; Krediet, T.G.; Van Loon, A.M.; A Verboon-Maciolek, M. Prognosis for neonates with enterovirus myocarditis. Arch. Dis. Child. Fetal Neonatal Ed. 2010, 95, F206-F212. [CrossRef] [PubMed]

59. Inwald, D.; Franklin, O.; Cubitt, D.; Peters, M.; Goldman, A.; Burch, M. Enterovirus myocarditis as a cause of neonatal collapse. Arch. Dis. Child. Fetal Neonatal Ed. 2004, 89, F461-F462. [CrossRef] [PubMed]

60. Lindower, J.B.; Bartlett, H.; Atkins, D.L.; Kim, J.O.; Klein, J.M.; Ford, B.A.; Morriss, F.H. Neonatal Enterovirus Infection: Case Series of Clinical Sepsis and Positive Cerebrospinal Fluid Polymerase Chain Reaction Test with Myocarditis and Cerebral White Matter Injury Complications. Am. J. Perinatol. Rep. 2016, 6, e344-e351. [CrossRef]

61. Madden, K.; Thiagarajan, R.R.; Rycus, P.T.; Rajagopal, S.K. Survival of neonates with enteroviral myocarditis requiring extracorporeal membrane oxygenation. Pediatr. Crit. Care Med. 2011, 12, 314-318. [CrossRef]

62. Modlin, J.F. Fatal Echovirus 11 Disease in Premature Neonates. Pediatrics 1980, 66, 775-780. [CrossRef]

63. Wang, J.; Atchison, R.W.; Walpusk, J.; Jaffe, R. Echovirus Hepatic Failure in Infancy: Report of Four Cases with Speculation on the Pathogenesis. Pediatr. Dev. Pathol. 2001, 4, 454-460. [CrossRef]

64. Abzug, M.J. Prognosis for neonates with enterovirus hepatitis and coagulopathy. Pediatr. Infect. Dis. J. 2001, 20, 758-763. [CrossRef]

65. Holm-Hansen, C.C.; Midgley, S.E.; Fischer, T.K. Global emergence of enterovirus D68: A systematic review. Lancet Infect. Dis. 2016, 16, e64-e75. [CrossRef]

66. Bosis, S.; Esposito, S. Enterovirus D68-Associated Community-Acquired Pneumonia in the Pediatric Age Group. Curr. Infect. Dis. Rep. 2017, 19. [CrossRef]

67. Liang, Z.; Pan, H.; Wang, X.; Zhu, Y.; Dang, Y.; Fan, X.; Gao, L.; Zhang, Z. Histopathological Features and Viral Antigen Distribution in the Lung of Fatal Patients with Enterovirus 71 Infection. Virol. Sin. 2018, 33, 278-281. [CrossRef]

68. Ho, M.; Chen, E.-R.; Hsu, K.-H.; Twu, S.-J.; Chen, K.-T.; Tsai, S.-F.; Wang, J.-R.; Shih, S.-R. An Epidemic of Enterovirus 71 Infection in Taiwan. N. Engl. J. Med. 1999, 341, 929-935. [CrossRef] 
69. Huang, W.-C.; Shih, W.-L.; Yang, S.-C.; Yen, T.-Y.; Lee, J.-T.; Huang, Y.-C.; Li, C.-C.; Hsieh, Y.-C.; Lin, T.-Y.; Chang, L.-Y.; et al. Predicting severe enterovirus 71 infection: Age, comorbidity, and parental behavior matter. J. Microbiol. Immunol. Infect. 2017, 50, 10-16. [CrossRef]

70. Kimmis, B.D.; Downing, C.; Tyring, S. Hand-foot-and-mouth disease caused by coxsackievirus A6 on the rise. Cutis 2018, 102, 353-356.

71. Ooi, M.H.; Wong, S.C.; Lewthwaite, P.; Cardosa, M.J.; Solomon, T. Clinical features, diagnosis, and management of enterovirus 71. Lancet Neurol. 2010, 9, 1097-1105. [CrossRef]

72. Mathes, E.F.; Oza, V.; Frieden, I.J.; Cordoro, K.M.; Yagi, S.; Howard, R.; Kristal, L.; Ginocchio, C.C.; Schaffer, J.; Maguiness, S.; et al. "Eczema Coxsackium" and Unusual Cutaneous Findings in an Enterovirus Outbreak. Pediatrics 2013, 132, e149-e157. [CrossRef] [PubMed]

73. Xu, S.; Li, H.; Qiao, P.; Xu, G.; Zhao, D.; Lin, X.; Qin, Y.; Yu, H.; Zhang, X.; Zhang, W.; et al. Neonatal hand, foot, and mouth disease due to coxsackievirus A6 in Shanghai. BMC Pediatr. 2020, 20, 1-8. [CrossRef] [PubMed]

74. King, R.L.; Lorch, S.A.; Cohen, D.M.; Hodinka, R.L.; Cohn, K.A.; Shah, S.S. Routine Cerebrospinal Fluid Enterovirus Polymerase Chain Reaction Testing Reduces Hospitalization and Antibiotic Use for Infants 90 Days of Age or Younger. Pediatrics 2007, 120, 489-496. [CrossRef] [PubMed]

75. Nigrovic, L.E.; Chiang, V.W. Cost Analysis of Enteroviral Polymerase Chain Reaction in Infants with Fever and Cerebrospinal Fluid Pleocytosis. Arch. Pediatr. Adolesc. Med. 2000, 154, 817-821. [CrossRef]

76. Ramers, C.; Billman, G.; Hartin, M.; Ho, S.; Sawyer, M.H. Impact of a Diagnostic Cerebrospinal Fluid Enterovirus Polymerase Chain Reaction Test on Patient Management. JAMA 2000, 283, 2680-2685. [CrossRef]

77. Verboon-Maciolek, M.A.; Nijhuis, M.; Van Loon, A.M.; Van Maarssenveen, N.; Van Wieringen, H.; Pekelharing-Berghuis, M.A.; Krediet, T.G.; Gerards, L.J.; Fleer, A.; Diepersloot, R.J.A.; et al. Diagnosis of Enterovirus Infection in the First 2 Months of Life by Real-Time Polymerase Chain Reaction. Clin. Infect. Dis. 2003, 37, 1-6. [CrossRef]

78. Dierssen, U.; Rehren, F.; Henke-Gendo, C.; Harste, G.; Heim, A. Rapid routine detection of enterovirus RNA in cerebrospinal fluid by a one-step real-time RT-PCR assay. J. Clin. Virol. 2008, 42, 58-64. [CrossRef] [PubMed]

79. Byington, C.L.; Taggart, E.W.; Carroll, K.C.; Hillyard, D.R. A polymerase chain reaction-based epidemiologic investigation of the incidence of nonpolio enteroviral infections in febrile and afebrile infants 90 days and younger. Pediatrics 1999, 103, e27. [CrossRef] [PubMed]

80. Paioni, P.; Barbey, F.; Relly, C.; Sauteur, P.M.M.; Berger, C. Impact of rapid enterovirus polymerase chain reaction testing on management of febrile young infants $<90$ days of age with aseptic meningitis. BMC Pediatr. 2020, 20, 1-7. [CrossRef]

81. Harvala, H.; Broberg, E.; Benschop, K.; Berginc, N.; Ladhani, S.; Susi, P.; Christiansen, C.; McKenna, J.; Allen, D.; Makiello, P.; et al. Recommendations for enterovirus diagnostics and characterisation within and beyond Europe. J. Clin. Virol. 2018, 101, 11-17. [CrossRef] [PubMed]

82. Daskou, M.; Dimitriou, T.; Alexopoulou, D.; Tsakogiannis, D.; Amoutzias, G.; Mossialos, D.; Kyriakopoulou, Z.; Markoulatos, P. WarmStart colorimetric RT-LAMP for the rapid, sensitive and specific detection of Enteroviruses A-D targeting the 5'UTR region. J. Appl. Microbiol. 2020, 130, 292-301. [CrossRef]

83. Chiu, C.Y.; Miller, S.A. Clinical metagenomics. Nat. Rev. Genet. 2019, 20, 341-355. [CrossRef] [PubMed]

84. Rittichier, K.R.; Bryan, P.A.; Bassett, K.E.; Taggart, E.W.; Enriquez, F.R.; Hillyard, D.R.; Byington, C. Diagnosis and Outcomes of Enterovirus Infections in Young Infants. Pediatr. Infect. Dis. J. 2005, 24, 546-550. [CrossRef]

85. Calvo, C.; Gallardo, P.; Torija, P.; Bellón, S.; Méndez-Echeverría, A.; Del Rosal, T.; Baquero-Artigao, F.; Sainz, T.; Romero, M.; Cabrerizo, M. Enterovirus neurological disease and bacterial coinfection in very young infants with fever. J. Clin. Virol. 2016, 85, 37-39. [CrossRef]

86. Drysdale, S.B.; Kelly, D.F. Fifteen-minute consultation: Enterovirus meningitis and encephalitis-when can we stop the antibiotics? Arch. Dis. Child. -Educ. Pract. 2016, 102, 66-71. [CrossRef] [PubMed]

87. Esposito, S.; Rahamat-Langendoen, J.; Ascolese, B.; Senatore, L.; Castellazzi, L.; Niesters, H. Pediatric parechovirus infections. J. Clin. Virol. 2014, 60, 84-89. [CrossRef] [PubMed]

88. Sharp, J.; Harrison, C.J.; Puckett, K.; Selvaraju, S.B.; Penaranda, S.; Nix, W.A.; Oberste, M.S.; Selvarangan, R. Characteristics of Young Infants in Whom Human Parechovirus, Enterovirus or Neither Were Detected in Cerebrospinal Fluid During Sepsis Evaluations. Pediatr. Infect. Dis. J. 2013, 32, 213-216. [CrossRef] [PubMed]

89. Baker, R.C.; Kummer, A.; Schultz, J.R.; Ho, M.; Del Rey, J.G. Neurodevelopmental Outcome of Infants with Viral Meningitis in the First Three Months of Life. Clin. Pediatr. 1996, 35, 295-301. [CrossRef]

90. Abzug, M.J.; Michaels, M.G.; Wald, E.; Jacobs, R.F.; Romero, J.R.; Sánchez, P.J.; Wilson, G.; Krogstad, P.; Storch, G.A.; Lawrence, R.; et al. A Randomized, Double-Blind, Placebo-Controlled Trial of Pleconaril for the Treatment of Neonates with Enterovirus Sepsis. J. Pediatr. Infect. Dis. Soc. 2015, 5, 53-62. [CrossRef]

91. Torres-Torres, S.; Myers, A.L.; Klatte, J.M.; Rhoden, E.E.; Oberste, M.S.; Collett, M.S.; McCulloh, R. First Use of Investigational Antiviral Drug Pocapavir (V-073) for Treating Neonatal Enteroviral Sepsis. Pediatr. Infect. Dis. J. 2015, 34, 52-54. [CrossRef]

92. Wittekind, S.G.; Allen, C.C.; Jefferies, J.L.; Rattan, M.S.; Madueme, P.C.; Taylor, B.N.; Moore, R.A. Neonatal Enterovirus Myocarditis with Severe Dystrophic Calcification: Novel Treatment With Pocapavir. J. Investig. Med. High Impact Case Rep. 2017, 5. [CrossRef] 
93. Amdani, S.M.; Kim, H.S.; Orvedahl, A.; John, A.O.; Said, A.; Simpson, K. Successful treatment of fulminant neonatal enteroviral myocarditis in monochorionic diamniotic twins with cardiopulmonary support, intravenous immunoglobulin and pocapavir. BMJ Case Rep. 2018, 2018. [CrossRef]

94. Laajala, M.; Reshamwala, D.; Marjomäki, V. Therapeutic targets for enterovirus infections. Expert Opin. Ther. Targets 2020, 24, 745-757. [CrossRef]

95. Vignuzzi, M.; Wendt, E.; Andino, R. Engineering attenuated virus vaccines by controlling replication fidelity. Nat. Med. 2008, 14, 154-161. [CrossRef]

96. Agudo, R.; Ferrer-Orta, C.; Arias, A.; De La Higuera, I.; Perales, C.; Pérez-Luque, R.; Verdaguer, N.; Domingo, E. A Multi-Step Process of Viral Adaptation to a Mutagenic Nucleoside Analogue by Modulation of Transition Types Leads to Extinction-Escape. PLoS Pathog. 2010, 6, e1001072. [CrossRef]

97. Abzug, M.J.; Keyserling, H.L.; Lee, M.L.; Levin, M.J.; Rotbart, H.A. Neonatal Enterovirus Infection: Virology, Serology, and Effects of Intravenous Immune Globulin. Clin. Infect. Dis. 1995, 20, 1201-1206. [CrossRef]

98. Yen, M.-H.; Huang, Y.-C.; Chen, M.-C.; Liu, C.-C.; Chiu, N.-C.; Lien, R.; Chang, L.-Y.; Chiu, C.-H.; Tsao, K.-C.; Lin, T.-Y. Effect of intravenous immunoglobulin for neonates with severe enteroviral infections with emphasis on the timing of administration. $J$. Clin. Virol. 2015, 64, 92-96. [CrossRef]

99. Modlin, J.F. Perinatal Echovirus Infection: Insights from a Literature Review of 61 Cases of Serious Infection and 16 Outbreaks in Nurseries. Clin. Infect. Dis. 1986, 8, 918-926. [CrossRef] [PubMed]

100. Chen, K.-T.; Chang, H.-L.; Wang, S.-T.; Cheng, Y.-T.; Yang, J.-Y. Epidemiologic Features of Hand-Foot-Mouth Disease and Herpangina Caused by Enterovirus 71 in Taiwan, 1998-2005. Pediatrics 2007, 120, e244-e252. [CrossRef] [PubMed]

101. Hu, Y.; Jiang, L.; Peng, H.-L. Clinical Analysis of 134 Children with Nervous System Damage Caused by Enterovirus 71 Infection. Pediatr. Infect. Dis. J. 2015, 34, 718-723. [CrossRef] [PubMed]

102. Chong, P.; Liu, C.-C.; Chow, Y.-H.; Chou, A.-H.; Klein, M. Review of Enterovirus 71 Vaccines. Clin. Infect. Dis. 2014, 60, 797-803. [CrossRef] [PubMed]

103. Zhu, F.-C.; Meng, F.-Y.; Li, J.-X.; Li, X.-L.; Mao, Q.-Y.; Tao, H.; Zhang, Y.-T.; Yao, X.; Chu, K.; Chen, Q.-H.; et al. Efficacy, safety, and immunology of an inactivated alum-adjuvant enterovirus 71 vaccine in children in China: A multicentre, randomised, double-blind, placebo-controlled, phase 3 trial. Lancet 2013, 381, 2024-2032. [CrossRef]

104. Wei, M.; Meng, F.; Wang, S.; Li, J.; Zhang, Y.; Mao, Q.; Hu, Y.; Liu, P.; Shi, N.; Tao, H.; et al. Two-year efficacy, immunogenicity, and safety of Vigoo Enterovirus 71 vaccine in healthy Chinese children: A randomised open-label study. J. Infect. Dis. 2016, 215, 56-63. [CrossRef]

105. Guan, X.; Che, Y.; Wei, S.; Li, S.; Zhao, Z.; Tong, Y.; Wang, L.; Gong, W.; Zhang, Y.; Zhao, Y.; et al. Effectiveness and Safety of an Inactivated Enterovirus 71 Vaccine in Children Aged 6-71 Months in a Phase IV Study. Clin. Infect. Dis. 2019, 71, 2421-2427. [CrossRef] 